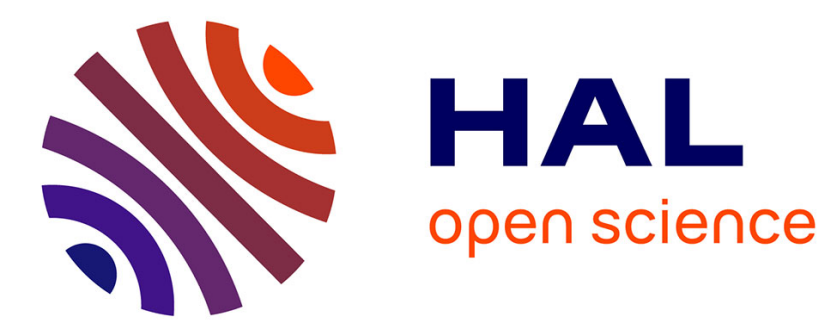

\title{
Strategic communication for women entrepreneurs: a case study of India
}

\author{
Maharaja Thandabhani
}

\section{To cite this version:}

Maharaja Thandabhani. Strategic communication for women entrepreneurs: a case study of India. Insights into Regional Development, 2020, 2 (1), pp.480-497. 10.9770/IRD.2020.2.1(7) . hal-02569369

\section{HAL Id: hal-02569369 \\ https://hal.science/hal-02569369}

Submitted on 11 May 2020

HAL is a multi-disciplinary open access archive for the deposit and dissemination of scientific research documents, whether they are published or not. The documents may come from teaching and research institutions in France or abroad, or from public or private research centers.
L'archive ouverte pluridisciplinaire HAL, est destinée au dépôt et à la diffusion de documents scientifiques de niveau recherche, publiés ou non, émanant des établissements d'enseignement et de recherche français ou étrangers, des laboratoires publics ou privés. 
INSIGHTS INTO REGIONAL DEVELOPMENT

ISSN 2669-0195 (online) http://jssidoi.org/IRD/

2020 Volume 2 Number 1 (March)

http://doi.org/10.9770/IRD.2020.2.1(7)

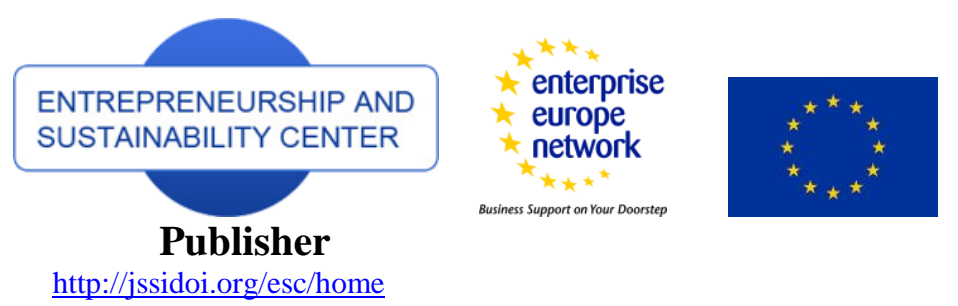

STRATEGIC COMMUNICATION FOR WOMEN ENTRREPRENEURS: A CASE STUDY OF INDIA*

Maharaja Thandabhani

\author{
Management Faculty, TIPS School of Management, 361/1A3B, Karuvalur Road, SS Kulam PO \\ Coimbatore 641107, Tamil Nadu, India \\ E-mail: modelimits@gmail.com
}

Received 16 November 2019; accepted 10 January 2019; published 30 March 2020

\begin{abstract}
Small and Medium Enterprises (SMEs) play a significant role in all economies and are key agents of employment, innovation and growth. Strategic communication is something different from normal communication as it involves with certain intelligent way of communicating the clients and counter parts. The implications of future of small industries, globalization, performance, perspectives and challenges would insist on prompt and prudent way of communicating and are to be confronted by women entrepreneurs. To crack the challenges and overcome the negative impacts of communication successfully, strategic communication becomes a vital part of business and entrepreneurs should familiarize such type of business communication for better decision-making in all functional areas of business. If information asymmetry exists, clients may respond by negatively leading to miscommunication or misinterpretation which will have bad effects on organization and business negotiations. The concept and source of communication should be adapted to have more clarity and transparency to make the receiver understand the information and message so as to make him/her respond appropriately. The consequence of inappropriate communication, or weak communication would exhaust the time and energy of the receiver leading to refusal of the clients or business partners. The fact is that most of the entrepreneurs from small and medium industries in India have not developed adequate expertise in strategic communication which may create setbacks in their business performances. This article analyses the profiles of the SME women entrepreneurs and their perception and expectation on strategic communication and their strategic communication components which are analyzed to derive the results.
\end{abstract}

Keywords: strategic communication; women entrepreneurs; communication components; small medium enterprises

Reference to this paper should be made as follows: Thandabhani, M. 2020. Strategic communication for women entrrepreneurs: a case study of India. Insights into Regional Development, 2(1), 480-497. http://doi.org/10.9770/IRD.2020.2.1(7)

JEL Classifications: L26, L63, L96

\title{
1. Introduction
}

Small and Medium enterprises play a significant role in all economies and are key agents of employment, innovation and growth. Small and medium firms play a key role in transition of the developing countries. These firms typically account for more than $90 \%$ of all firms outside the agricultural sector, constitute a major source of employment and generate significant domestic and export earnings. As such, women SME development emerges as a key instrument in the small and medium enterprises and economic development of our nation.

\footnotetext{
* This research was partly supported by Entrepreneurship and Sustainability Center, Lithuania
} 


\section{INSIGHTS INTO REGIONAL DEVELOPMENT}

ISSN 2669-0195 (online) http://jssidoi.org/jesi/

2020 Volume 2 Number 1 (March)

http://doi.org/10.9770/IRD.2020.2.1(7)

Communication is necessary at every stage of a business life cycle. It is required to help women SMEs set up and expand their operations, and to develop new products. India has a well developed communication system, comprising Social media, mobile networks, supply chain operators, logistics companies, banks and financial institutions, courier services, ICT companies and other corporate companies. The growing significance of Small and Medium Enterprises (SMEs) for employment and income generation, and the development of women entrepreneurs have led various businesses and international organizations to support their development and expansion (e.g. Morris et al., 2002; Argenti, 2003; Bala Subrahmanya, 2004; UNCTAD 2014; Iacob, Hristache, 2017; Akhter, 2017; Jimenez-Marin et al. 2018; Njaramba et al., 2018; Prodani et al. 2019; Benešová, Hušek, 2019).

\section{Communication for women entrepreners}

One of the major challenges faced by the women SMEs is access to timely and strategic communication. Access on a global basis to modern communication technology is possible for the women entrepreneurs like their male counterparts. When it comes for communicating strategically, there lies the question how far the women entrepreneurs could communicate strategically in every business situation to become successful. Their capability in communicating strategically has become the most critical determinant of international competitiveness.

The international business situation demands the need for strategic communication of women SMEs to be internationally competitive in terms of quality, delivery, after-sales service, price, etc. Strategic communication would be a prerequisite in all areas of business to bring about transformation in the business. The problem is that the availability of adequate communication skills to act upon the entrepreneurial positions and to strike a balance between the business requirement and the strategies to be applied through effective communication becomes critical for Indian women entrepreneurs.

\section{Objective}

The article has the following objectives.

1. To identify and analyze the association between the profile of the Women SME entrepreneurs and their perception of communication on various factors of their business footings.

2. To examine the level of expectation on various factors in strategic communication among the women SME entrepreneurs and its association with their profile.

3. To ascertain the effectiveness of communication over the perception and expectation of women SME entrepreneurs.

\section{Method}

In this paper, the descriptive, empirical research and related research designs have been administered. This study analyzes the expectation and perception on strategic communication among the Women SME entrepreneurs of Coimbatore district, Tamil Nadu state in India. With that their profiles have been analyzed by applying Correlation.

Systematic sampling technique has been used in this study. A sample size of 435 women SME entrepreneurs was finally filtered to $172 \mathrm{SME}$ women entrepreneurs and contacted directly to get their responses through interview method. Seven such communication components namely Completeness, Courtesy, Correctness, Clarity, Consideration, Conciseness and Creativity have been identified and applied in this study. These strategic communication components and their relationship with the selected profile of the women SME entrepreneurship were analyzed and results, discussion and conclusion were made. 
A questionnaire was administered among the women SME entrepreneurs in order to get their responses. The responses were analyzed and tabulated to derive the results and discussion.

\section{Analysis}

\section{Degree of relationship between selected profiles of the women entrepreneurs and their level of perception on strategic communication and it components}

The relationship between the selected profiles of the women entrepreneurs and their level of perception on strategic communication is found by using correlation analysis.

Table 1. Degree of relationship between selected profiles of the women entrepreneurs and their perception on completeness

\begin{tabular}{|c|l|c|c|}
\hline No. & \multicolumn{1}{|c|}{ Independent variables } & 'r' value & 'p' value \\
\hline 1. & Age & -0.436 & $0.000^{*}$ \\
\hline 2. & Educational Qualification & -0.690 & $0.000^{*}$ \\
\hline 3. & Working Experience & -0.238 & $0.000^{*}$ \\
\hline 4. & Number of employees working in the company & 0.247 & $0.000^{*}$ \\
\hline 5. & Annual Turnover & -0.036 & $0.457^{\mathrm{NS}}$ \\
\hline
\end{tabular}

It is noted from the table 1 and figure 1 that among the five selected profiles of the women entrepreneurs, only one factor viz. number of employees working in the company have positive correlation with the perception on completeness.

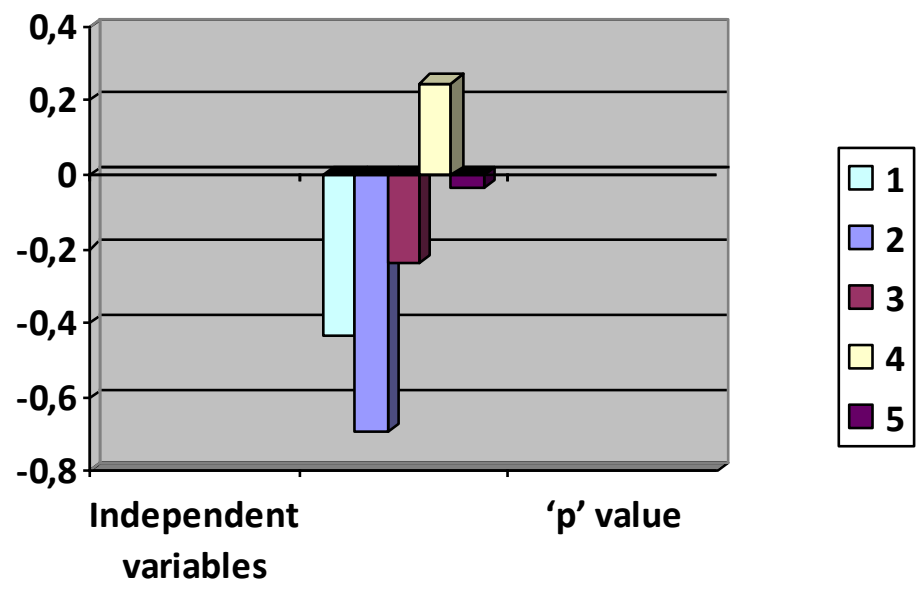

Fig. 1. Completeness Source: Table 1 
Table 2. Degree of relationship between selected profiles of the women entrepreneurs and their perception on courtesy

\begin{tabular}{|c|l|l|l|}
\hline No. & \multicolumn{1}{|c|}{ Independent variables } & \multicolumn{1}{|c|}{ 'r' value 'p' value } & \multicolumn{1}{|c|}{} \\
\hline 1. & Age & 0.545 & $0.000^{*}$ \\
\hline 2. & Educational Qualification & 0.000 & $0.996^{\mathrm{NS}}$ \\
\hline 3. & Working Experience & 0.403 & $0.000^{*}$ \\
\hline 4. & Number of employees working in the company & -0.360 & $0.000^{*}$ \\
\hline 5. & Annual Turnover & -0.094 & $0.049^{* *}$ \\
\hline
\end{tabular}

Note: * - Significant at 1\% level; ** - Significant at 5\% level; NS - Not Significant

It is divulged from the table 2 and figure 2that among the five selected profiles of women entrepreneurs, two factors viz. age and working experience have positive correlation with the perception on courtesy.

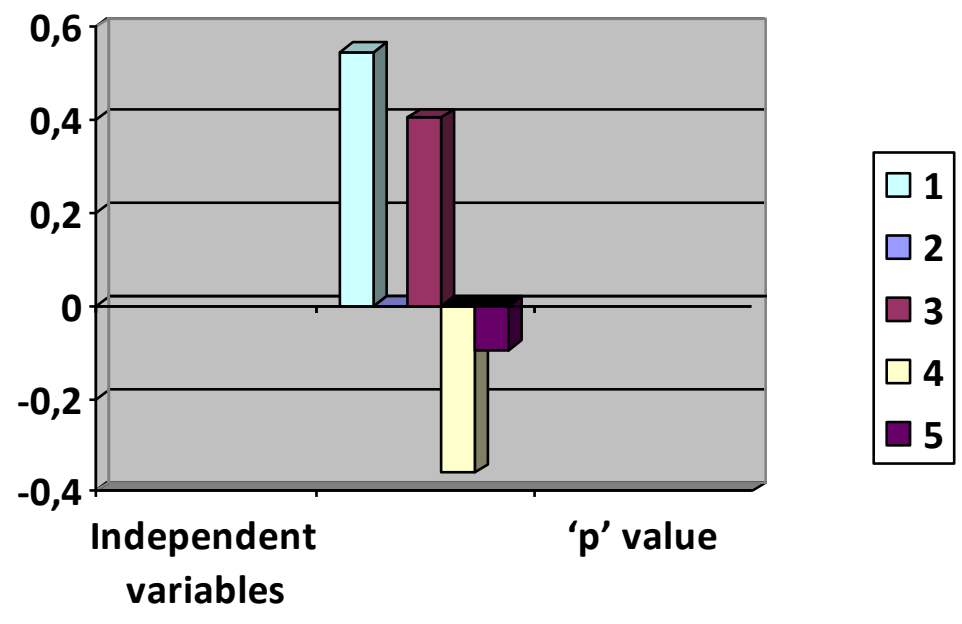

Fig. 2. Courtesy

Source: Table 2

Table 3. Degree of relationship between selected profiles of the women entrepreneurs and their perception on correctness

\begin{tabular}{|c|l|c|c|}
\hline No. & \multicolumn{1}{|c|}{ Independent variables } & 'r' value 'p' value & \\
\hline 1. & Age & -0.427 & $0.000^{*}$ \\
\hline 2. & Educational Qualification & -0.059 & $0.219^{\mathrm{NS}}$ \\
\hline 3. & Working Experience & 0.338 & $0.000^{*}$ \\
\hline
\end{tabular}


INSIGHTS INTO REGIONAL DEVELOPMENT

ISSN 2669-0195 (online) http://jssidoi.org/jesi/

2020 Volume 2 Number 1 (March)

http://doi.org/10.9770/IRD.2020.2.1(7)

\begin{tabular}{|c|l|c|c|}
\hline No. & \multicolumn{1}{|c|}{ Independent variables } & ' $r$ ' value & 'p' value \\
\hline 4. & Number of employees working in the company & -0.574 & $0.000^{*}$ \\
\hline 5. & Annual Turnover & -0.024 & $0.612^{\mathrm{NS}}$ \\
\hline
\end{tabular}

Note: * - Significant at $1 \%$ level; NS - Not Significant

It is observed from table 3 and figure 3 that among the five selected profiles of the women entrepreneurs, only one factor viz. working experience has positive correlation with perception on correctness.

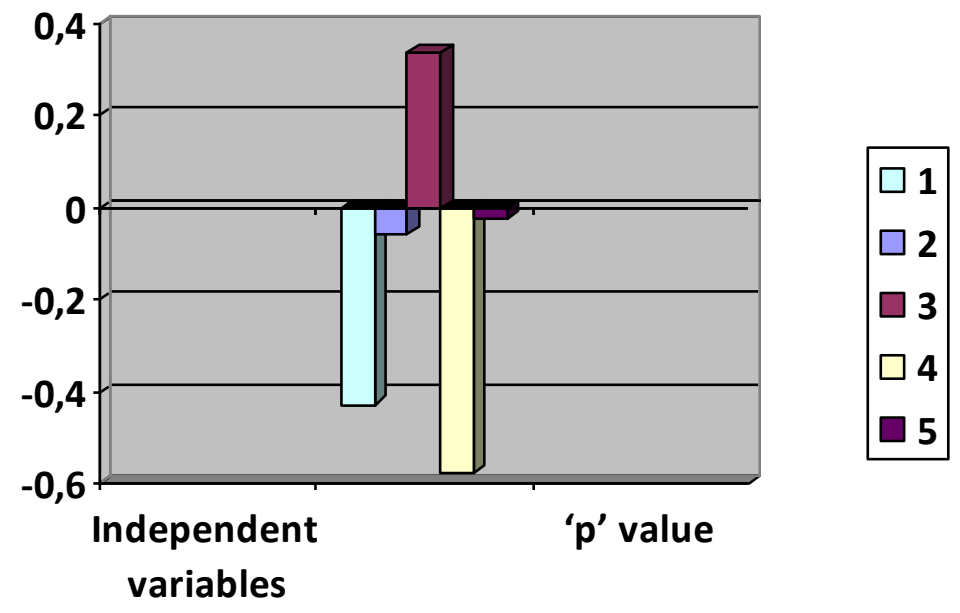

Fig. 3. Correctness

Source: Table 3

Table 4. Degree of relationship between selected profiles of the women entrepreneurs and their perception on clarity

\begin{tabular}{|c|l|c|c|}
\hline No. & \multicolumn{1}{|c|}{ Independent variables } & 'r' value & 'p' value \\
\hline 1. & Age & 0.464 & $0.000^{*}$ \\
\hline 2. & Educational Qualification & 0.354 & $0.000^{*}$ \\
\hline 3. & Working Experience & -0.206 & $0.000^{*}$ \\
\hline 4. & Number of employees working in the company & -0.116 & $0.015^{* *}$ \\
\hline 5. & Annual Turnover & -0.025 & $0.607^{\mathrm{NS}}$ \\
\hline
\end{tabular}

Note: * - Significant at $1 \%$ level; ** - Significant at 5\% level; NS - Not Significant

It is observed from the table 4 and figure 4 that among the five selected profile of the women entrepreneurs, two factors viz. age and educational qualification have positive correlation with the perception on clarity. 


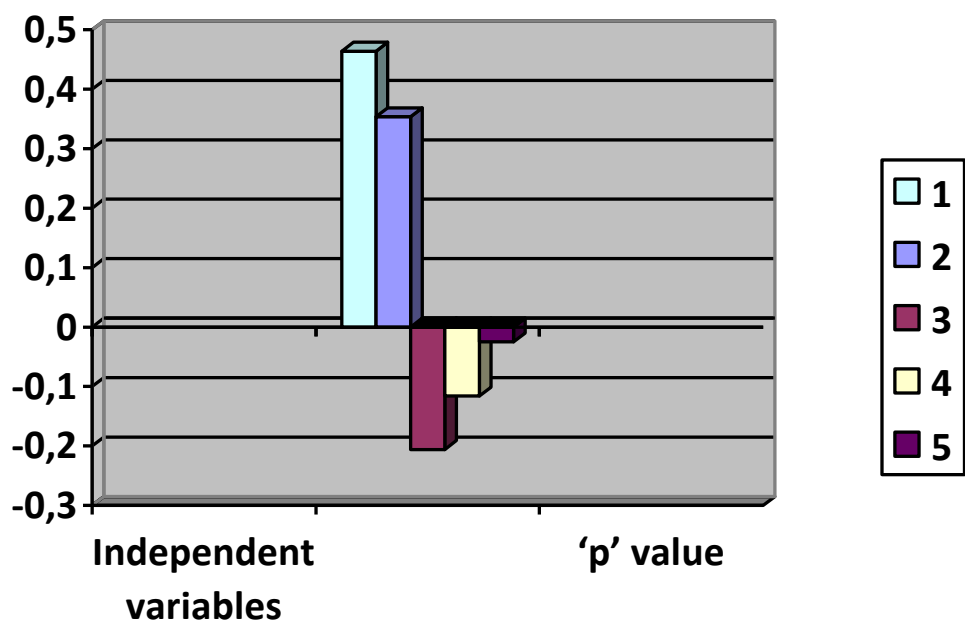

Fig. 4. Clarity Source: Table 4

Table 5. Degree of relationship between selected profiles of the Women entrepreneurs and their perception on consideration

\begin{tabular}{|c|l|c|c|}
\hline No. & \multicolumn{1}{|c|}{ Independent variables } & 'r' value 'p' value & ' \\
\hline 1. & Age & -0.037 & $0.437^{\mathrm{NS}}$ \\
\hline 2. & Educational Qualification & -0.564 & $0.000^{*}$ \\
\hline 3. & Working Experience & 0.321 & $0.000^{*}$ \\
\hline 4. & Number of employees working in the company & 0.018 & $0.714^{\mathrm{NS}}$ \\
\hline 5. & Annual Turnover & -0.290 & $0.000^{*}$ \\
\hline
\end{tabular}

Note: * - Significant at $1 \%$ level; NS - Not Significant

It is inferred from the table 5 and figure 5 that among the five selected profiles of the Women entrepreneurs, only one factor viz. working experience have positive correlation with the perception on consideration. 


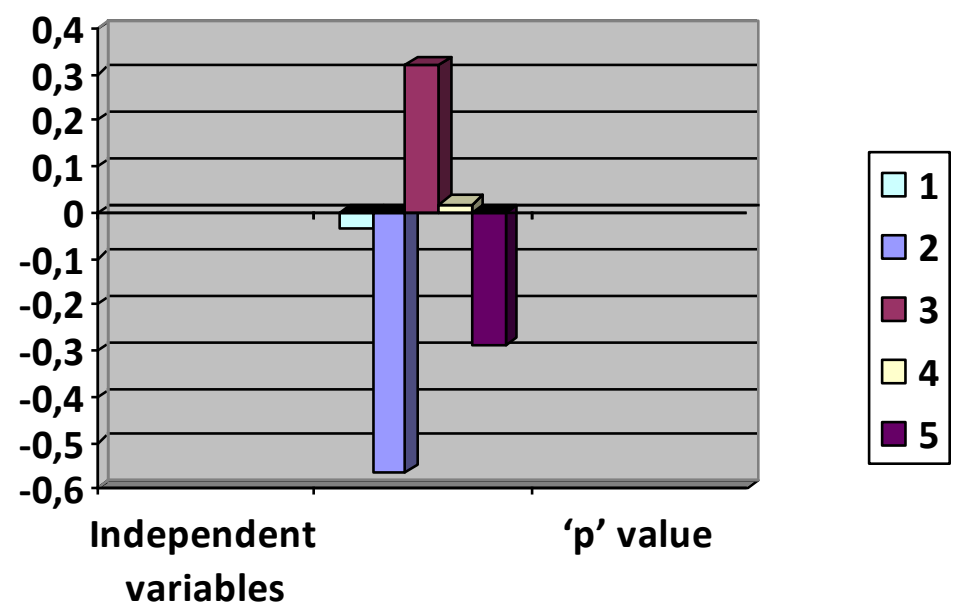

Fig. 5. Consideration Source: Table 5

Table 6. Degree of relationship between selected profiles of the women entrepreneurs and their perception on conciseness

\begin{tabular}{|c|l|c|c|}
\hline No. & \multicolumn{1}{|c|}{ Independent variables } & ' $r$ ' value & 'p' value \\
\hline 1. & Age & -0.010 & $0.840^{\mathrm{NS}}$ \\
\hline 2. & Educational Qualification & -0.017 & $0.718^{\mathrm{NS}}$ \\
\hline 3. & Working Experience & 0.408 & $0.000^{*}$ \\
\hline 4. & Number of employees working in the company & -0.301 & $0.000^{*}$ \\
\hline 5. & Annual Turnover & 0.523 & $0.000 *$ \\
\hline
\end{tabular}

Note: * - Significant at $1 \%$ level; NS - Not Significant

It is inferred from the table 6 and figure 6 that all the five selected profiles of the Women entrepreneurs, two factors viz. working experience and annual turnover have positive correlation with the perception on conciseness. 


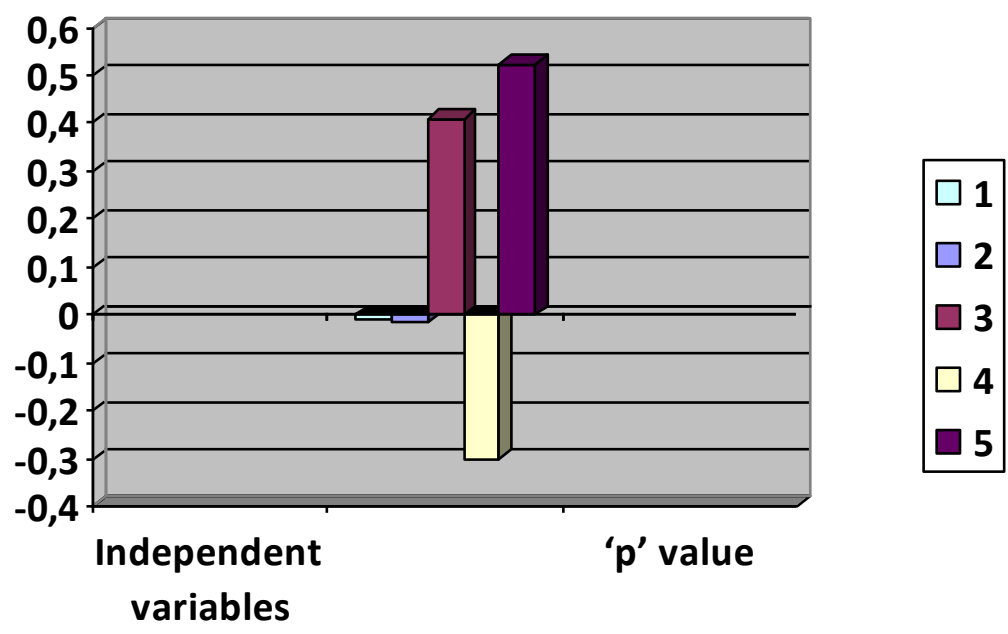

Fig. 6. Conciseness Source: Table 6

Table 7. Degree of relationship between selected profiles of the Women entrepreneurs and their perception on creativity

\begin{tabular}{|c|l|c|c|}
\hline No. & \multicolumn{1}{|c|}{ Independent variables } & 'r' value ' $p$ ' value \\
\hline 1. & Age & -0.133 & $0.005^{*}$ \\
\hline 2. & Educational Qualification & -0.083 & $0.085^{\mathrm{NS}}$ \\
\hline 3. & Working Experience & 0.166 & $0.001^{*}$ \\
\hline 4. & Number of employees working in the company & 0.047 & $0.331^{\mathrm{NS}}$ \\
\hline 5. & Annual Turnover & 0.344 & $0.000^{*}$ \\
\hline
\end{tabular}

Note: * - Significant at $1 \%$ level; NS - Not Significant

It is noted from the table 7 and figure 7 that among the five selected profiles of the women entrepreneurs, two factor viz. working experience and annual turnover have positive correlation with the perception on creativity. 


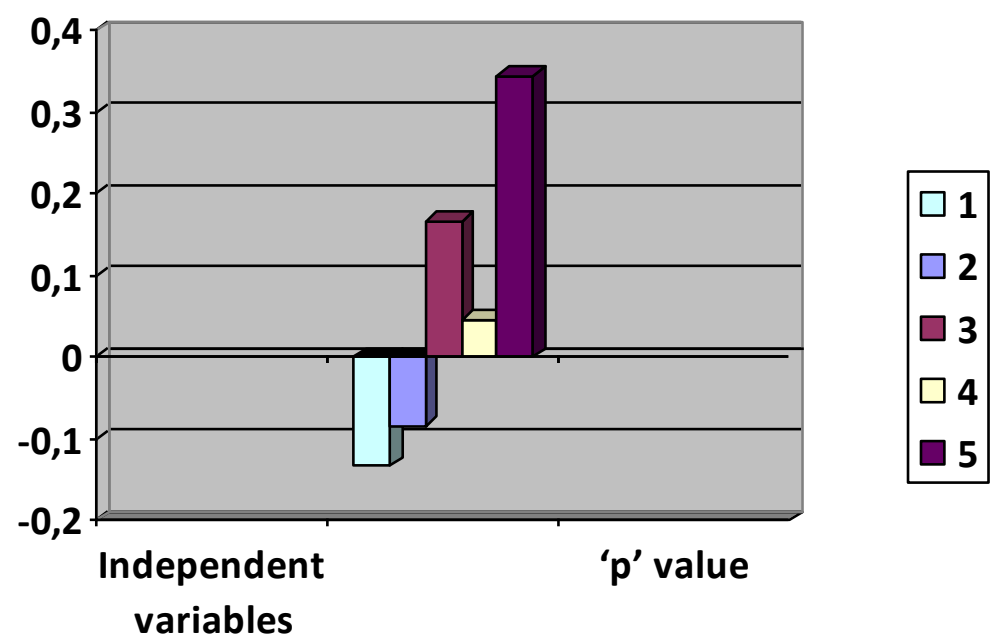

Fig.7. Creativity Source: Table 7

\section{Degree of relationship between selected profiles of the women entrepreneurs and their expectation on strategic communication}

The relationship between the profiles of the women entrepreneurs and the expectation on strategic communication components is found by using correlation analysis. The independent variables are namely age, educational qualification, working experience, number of employees working in the company and annual turnover.

Table 8. Degree of relationship between selected profiles of the women entrepreneurs and their expectation on completeness

\begin{tabular}{|c|l|c|c|}
\hline No. & \multicolumn{1}{|c|}{ Independent variables } & 'r' value & 'p' value \\
\hline 1. & Age & 0.356 & $0.000^{*}$ \\
\hline 2. & Educational Qualification & 0.084 & $0.080^{\mathrm{NS}}$ \\
\hline 3. & Working Experience & 0.121 & $0.012^{* *}$ \\
\hline 4. & Number of employees working in the company & 0.339 & $0.000^{*}$ \\
\hline 5. & Annual Turnover & 0.229 & $0.000^{*}$ \\
\hline
\end{tabular}

Note: * - Significant at $1 \%$ level; ** - Significant at $5 \%$ level; NS - Not Significant

It is inferred from the table 8 and figure 8 that among the five selected profiles of the women entrepreneurs, four factors viz. age, working experience, number of employees working in the company and annual turnover have positive correlation with the expectation on completeness. 


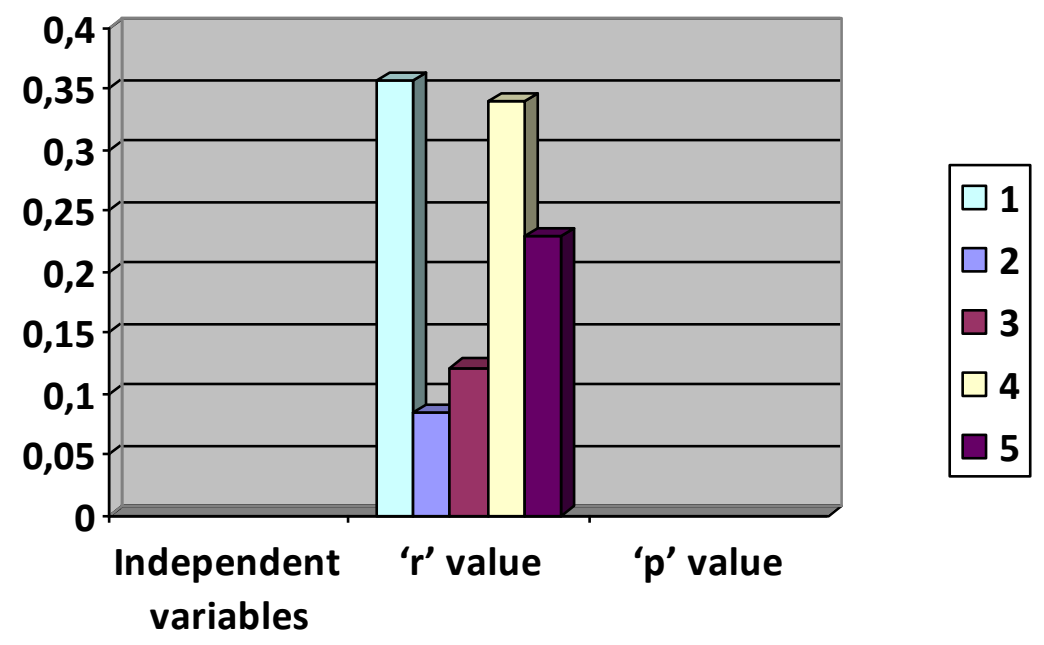

Fig. 8. Completeness Source: Table 8

Table 9. Degree of relationship between selected profiles of the women entrepreneurs and their expectation on courtesy

\begin{tabular}{|c|l|c|c|}
\hline No. & \multicolumn{1}{|c|}{ Independent variables } & 'r' value & 'p' value \\
\hline 1. & Age & -0.039 & $0.412^{\mathrm{NS}}$ \\
\hline 2. & Educational Qualification & 0.220 & $0.000^{*}$ \\
\hline 3. & Working Experience & 0.229 & $0.000^{*}$ \\
\hline 4. & Number of employees working in the company & 0.176 & $0.000^{*}$ \\
\hline 5. & Annual Turnover & 0.281 & $0.000^{*}$ \\
\hline
\end{tabular}

Note: * - Significant at $1 \%$ level; NS - Not Significant

It can be revealed from the table 9 and figure 9 that among the five selected profiles of the women entrepreneurs, four factors viz. educational qualification, working experience, number of employees working in the company and annual turnover have positive correlation with the expectation on courtesy. 


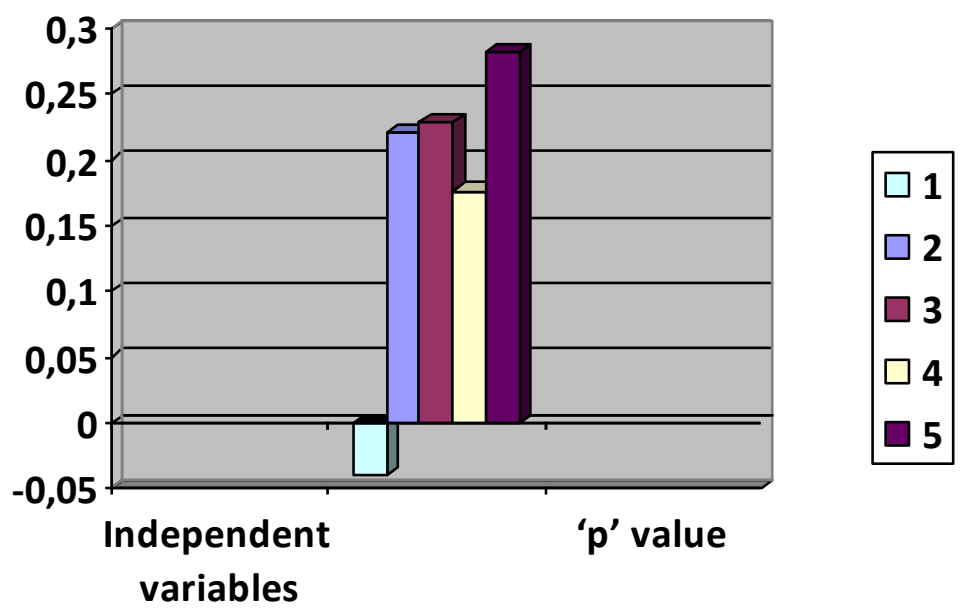

Fig. 9. Courtesy Source: Table 9

Table 10. Degree of relationship between selected profiles of the women entrepreneurs and their expectation on correctness

\begin{tabular}{|c|l|c|c|}
\hline No. & \multicolumn{1}{|c|}{ Independent variables } & 'r' value & 'p' value \\
\hline 1. & Age & -0.124 & $0.010^{*}$ \\
\hline 2. & Educational Qualification & 0.031 & $0.513^{\mathrm{NS}}$ \\
\hline 3. & Working Experience & 0.278 & $0.000^{*}$ \\
\hline 4. & Number of employees working in the company & 0.277 & $0.000^{*}$ \\
\hline 5. & Annual Turnover & -0.122 & $0.011^{* *}$ \\
\hline
\end{tabular}

Note: * - Significant at $1 \%$ level; ** - Significant at 5\% level; NS - Not Significant

It is noted from the table 10 and figure 10 that among the five selected profiles of the women entrepreneurs, two factors viz. working experience and number of employees working in the company have positive correlation with the expectation on correctness. 


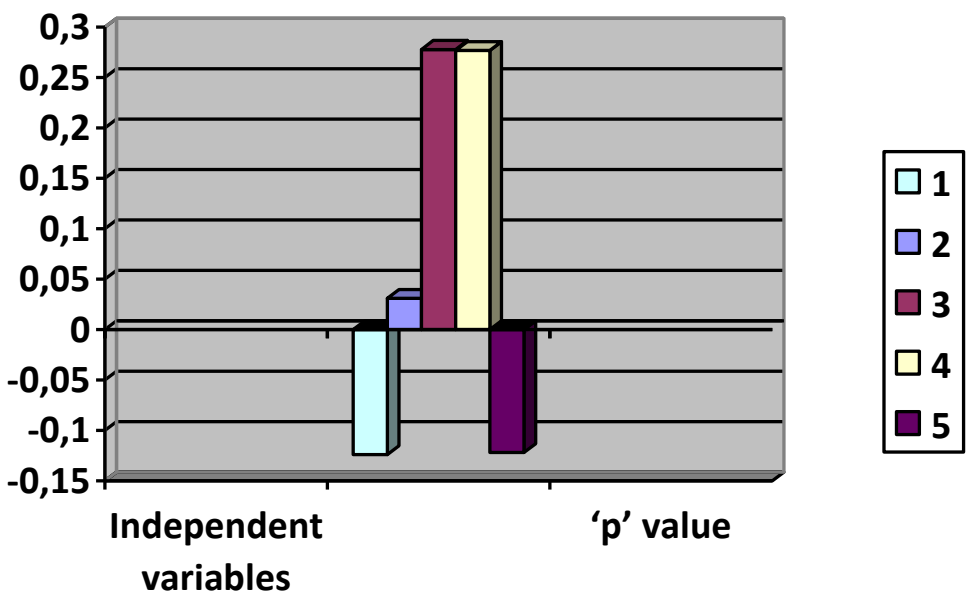

Fig.10. Correctness

Source: Table 10

Table 11. Degree of relationship between selected profiles of the women entrepreneurs and their expectation on clarity

\begin{tabular}{|c|l|c|c|}
\hline No. & \multicolumn{1}{|c|}{ Independent variables } & 'r' value & 'p' value \\
\hline 1. & Age & 0.510 & $0.000^{*}$ \\
\hline 2. & Educational Qualification & 0.120 & $0.012^{* *}$ \\
\hline 3. & Working Experience & -0.041 & $0.397^{\text {NS }}$ \\
\hline 4. & Number of employees working in the company & 0.445 & $0.000^{*}$ \\
\hline 5. & Annual Turnover & 0.345 & $0.000^{*}$ \\
\hline
\end{tabular}

Note: $*$ - Significant at $1 \%$ level; $* *$ - Significant at $5 \%$ level; NS - Not Significant

It is observed from the table 11 and figure 11 that among the five selected profiles of the women entrepreneurs, four factors viz. age, educational qualification, number of employees working in the company and annual turnover have positive correlation with the expectation on clarity. 


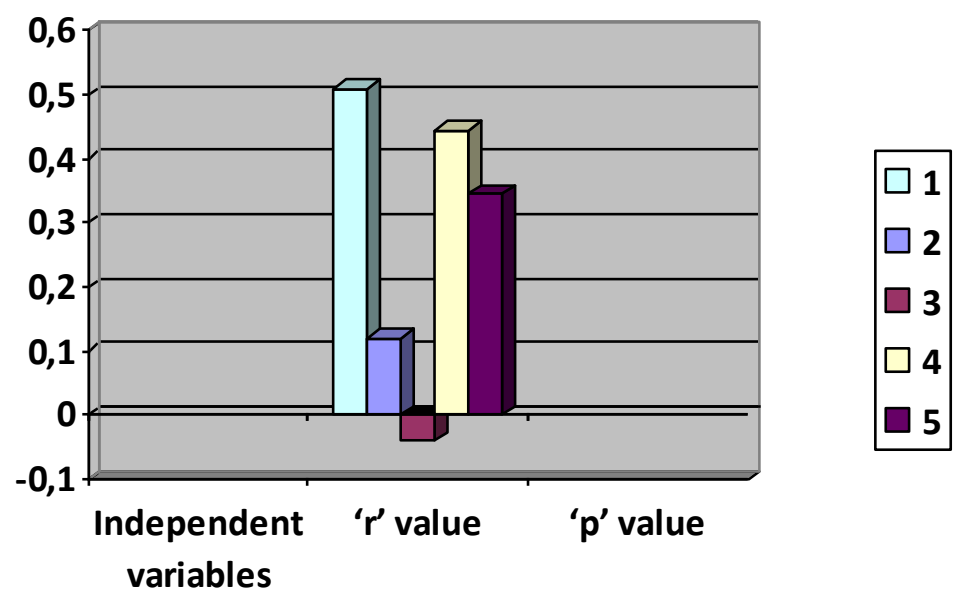

Fig. 11. Clarity Source: Table 11

Table 12. Degree of relationship between selected profiles of the women entrepreneurs and their expectation on consideration

\begin{tabular}{|c|l|c|c|}
\hline No. & \multicolumn{1}{|c|}{ Independent variables } & 'r' value & 'p' value \\
\hline 1. & Age & -0.008 & $0.863^{\mathrm{NS}}$ \\
\hline 2. & Educational Qualification & 0.330 & $0.000^{*}$ \\
\hline 3. & Working Experience & -0.084 & $0.082^{\mathrm{NS}}$ \\
\hline 4. & Number of employees working in the company & 0.418 & $0.000^{*}$ \\
\hline 5. & Annual Turnover & 0.352 & $0.000^{*}$ \\
\hline
\end{tabular}

Note: * - Significant at $1 \%$ level; NS - Not Significant

It is divulged from the table 12 and figure 12 that among the five selected profiles of the women entrepreneurs, three factors viz. educational qualification, number of employees working in the company and annual turnover have positive correlation with the expectation on consideration. 


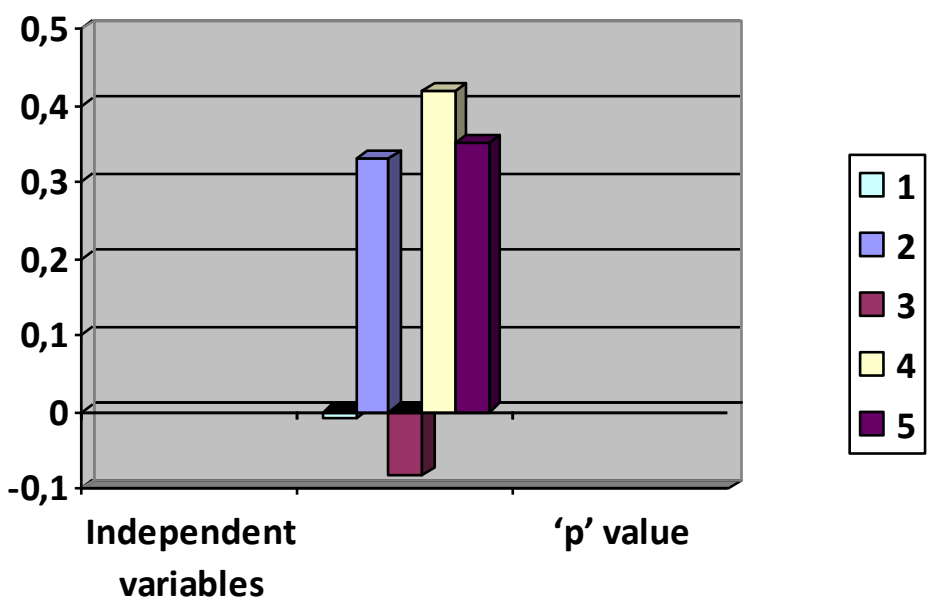

Fig.12. Consideration Source: Table 12

Table 13. Degree of relationship between selected profiles of the women entrepreneurs and their expectation on conciseness

\begin{tabular}{|c|l|c|c|}
\hline No. & \multicolumn{1}{|c|}{ Independent variables } & 'r' value & 'p' value \\
\hline 1. & Age & -0.033 & $0.491^{\mathrm{NS}}$ \\
\hline 2. & Educational Qualification & 0.489 & $0.000^{*}$ \\
\hline 3. & Working Experience & 0.219 & $0.000^{*}$ \\
\hline 4. & Number of employees working in the company & 0.036 & $0.448^{\mathrm{NS}}$ \\
\hline 5. & Annual Turnover & -0.102 & $0.033^{* *}$ \\
\hline
\end{tabular}

Note: * - Significant at 1\% level; ** - Significant at 5\% level; NS - Not Significant

It is inferred from the table 13 and figure 13 that among the five selected profiles of the women entrepreneurs, two factors viz. educational qualification and working experience have positive correlation with the expectation on conciseness. 


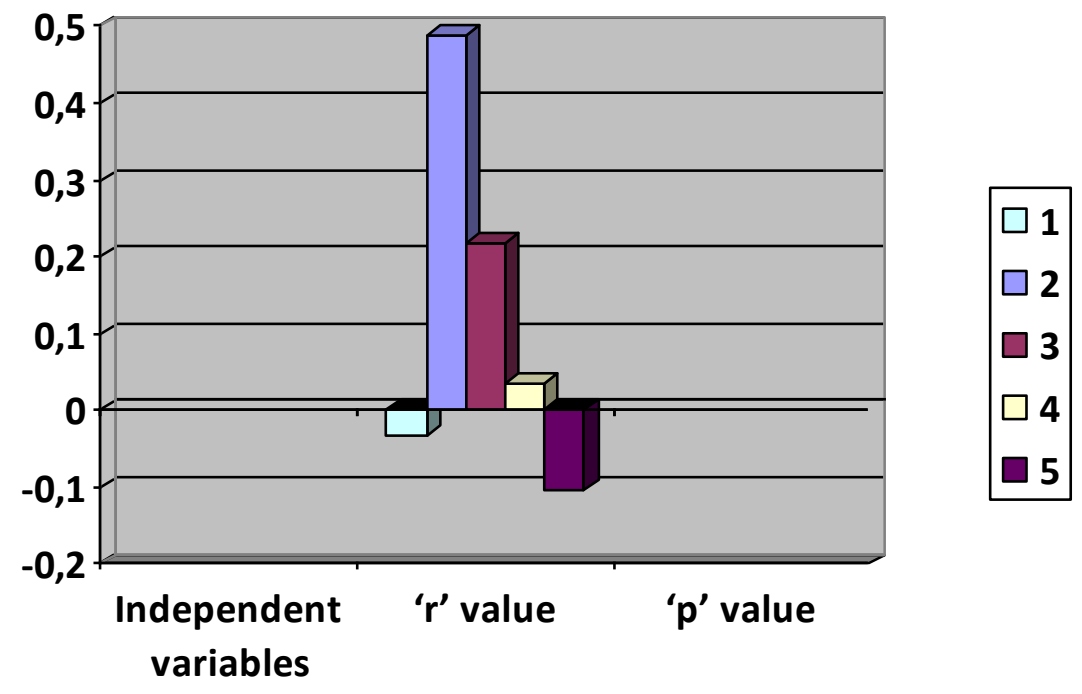

Fig.13. Conciseness Source: Table 13

Table 14. Degree of relationship between selected profiles of the women entrepreneurs and their expectation on creativity

\begin{tabular}{|c|l|c|c|}
\hline No. & \multicolumn{1}{|c|}{ Independent variables } & ' $r$ ' value & 'p' value \\
\hline 1. & Age & 0.010 & $0.835^{\mathrm{NS}}$ \\
\hline 2. & Educational Qualification & 0.228 & $0.000^{*}$ \\
\hline 3. & Working Experience & 0.327 & $0.000^{*}$ \\
\hline 4. & Number of employees working in the company & 0.345 & $0.000^{*}$ \\
\hline 5. & Annual Turnover & 0.103 & $0.011^{* *}$ \\
\hline
\end{tabular}

Note: * - Significant at 1\% level; ** - Significant at 5\% level; NS - Not Significant

It is noted from the table 14 and figure 14 that among the five selected profiles of the women entrepreneurs, four factors viz. educational qualification, working experience, number of employees working in the company and annual turnover have positive correlation with the expectation on creativity. 


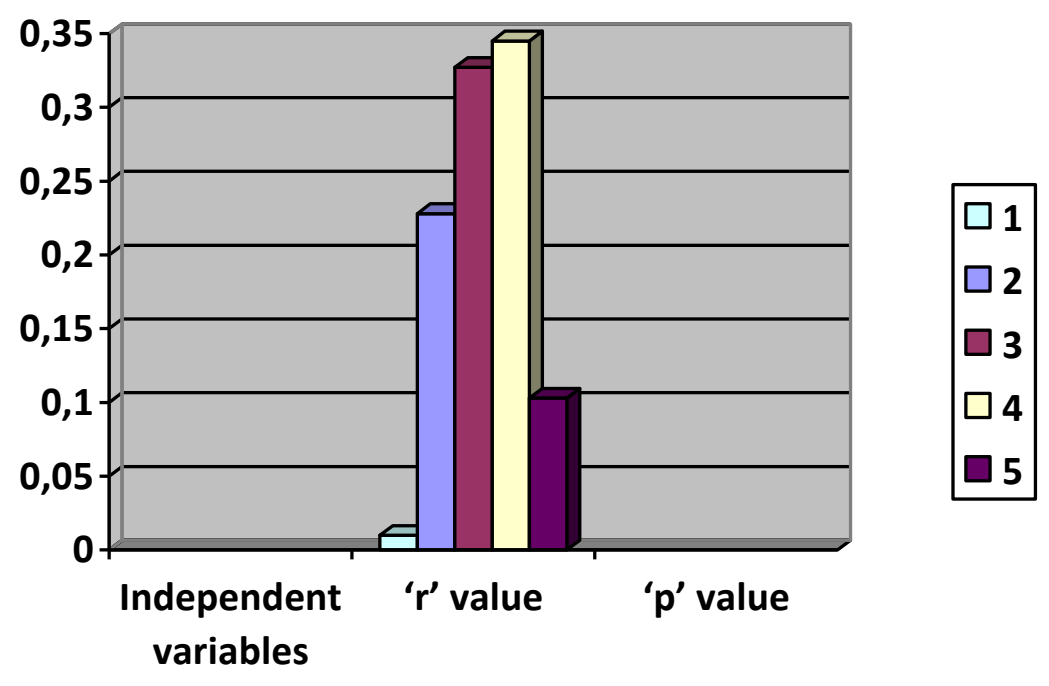

Fig. 14. Creativity Source: Table 14

\section{Results}

From the research paper, it is noted that even though the small size enterprise women entrepreneurs are having above 10 years experience in their business they are expecting more completeness on both the entrepreneurs and services to the clients. The clients and counterparts may provide administrative as well as technical help to women SMEs through resorting to proper strategic communication based on the 7c's of communication. Women entrepreneurs and their role towards the components of communication can help in protecting the relationship with their clients to great extent that increases the effectiveness of communication and make it to be strategic in nature for the women entrepreneurs once they have a very right perception and their expectation.

- $\quad$ Regarding the installed capacity, production, and extent of demand and so on and they are unable to assess the present condition and future prospects of women SMEs. So, it is recommended to the women SMEs, they should apply all the communication components required to communicate that give more effect and to facilitate the women entrepreneurs to achieve the desired responses. Hence, as the strategic communication of the women entrepreneurs has been powered through applying the communication components rightly would automatically formulate strategies over their communication and increase the clients' interest over the organizations and respective entrepreneurs.

- $\quad$ Strategic communication practices should be one of the important practices especially for women SMEs even though they may hire administrative assistants. Small firms may not be able to appoint assistants for this purpose who can assist the women entrepreneurs in strategic communication. So, it is recommended that women entrepreneurs should undergo necessary communication practice and training to enhance their communication potential. It is not only important for the entrepreneurs to update their knowledge in every source and channel of mainstream communication throughout the business period, but also to enhance their power of communication through training opportunities and mentoring in the communication field. These only can synergize the effectiveness of the women entrepreneurs' communication. 


\section{INSIGHTS INTO REGIONAL DEVELOPMENT}

ISSN 2669-0195 (online) http://jssidoi.org/jesi/

2020 Volume 2 Number 1 (March)

http://doi.org/10.9770/IRD.2020.2.1(7)

\section{Conclusion}

Strategic communication should be understood in Small and Medium Enterprises (SMEs) and due importance to been given to practice especially the women entrprenuers. In his article, "Perceptions of SME Growth Constraints in Nigeria", Charles 2002, identifies that one of the constraints for entrepreneurs is effective communication. By considering its sheer size, it is felt that the concept of women entrepreneurs have become crucial and it is the very time to generalize the importance and need to improve the communication skills and update their knowledge over communication ICT resources and channels available in the business field.

This may also minimize the cost and time of communication. But, the counterparts do not consider the women SME entrepreneurs and their credentials unless they are good at communicating their counter parts to make the communication more effective. Obviously, this study identifies seven communication components by which the strategic communication of the women entrepreneurs could be enhanced if properly applied and taken up as an exercise could open even the gateway for efficient global .

\section{References}

Akhter, F. 2017. Unlocking digital entrepreneurship through technical business process. Entrepreneurship and Sustainability Issues, 5(1), 36-42. http://doi.org/10.9770/jesi.2017.5.1(3)

Argenti, P.A. 2003. Corporate communication. Boston: McGraw-Hill Irwin. ISBN-13: 978-0073403175

Bala Subrahmanya, M. H. 2004. Small Industry and Globalization: Implications, Performance and Prospects. Economic and Political Weekly, XXXIX(18), 1826-1834.

Benešová, D., Hušek, M. 2019. Factors for efficient use of information and communication technologies influencing sustainable position of service enterprises in Slovakia. Entrepreneurship and Sustainability Issue,s 6(3), 1082-1094. http://doi.org/10.9770/jesi.2019.6.3(9)

Charles, M. 2002. Perceptions of SME Growth Constraints in Nigeria. Journal of Small Business Management, 40(1), 58-65. http://dx.doi.org/10.1111/1540-627X.00039

Iacob, S.E., Hristache, D.A. 2017. Entrepreneurship communication and its role in business management, Economics and Applied Informatics, 3, 226-229. www.eia.feaa.ugal.ro

Jimenez-Marin, G., Zambrano, R.E., Bellido-Perrez, E. 2018. The Entrepreneurship in communication as an Educational - learning Method: University Teaching and educommunication, pp. 364-374. http://dx.doi.org/10.5772/intechopen.71369

Morris, M.H., Schindehutte, M., La Forge, R.W. 2002. Entrepreneurial marketing: A construct for integrating emerging entrepreneurship and marketing perspectives. Journal of Marketing Theory and Practice, 10(4), 1-19 https://doi.org/10.1080/10696679.2002.11501922

Njaramba, J, Chigeza, P, Whitehouse, H. 2018. Barriers and challenges experienced by migrant African women entrepreneurs in North Queensland, Australia. Entrepreneurship and Sustainability Issues, 5(4), 1054-1068. http://doi.org/10.9770/jesi.2018.5.4(25)

Prodani, R., Bushati, J., Andersons, A. 2019. An assessment of impact of information and communication technology in enterprizes of Korça region. Insights into Regional Development, 1(4), 333-342. https://doi.org/10.9770/ird.2019.1.4(4)

UNCTAD 2014. Empowering Women Entrepreneurs through Information and Communications Technologies https://unctad.org/en/PublicationsLibrary/dtlstict2013d2_en.pdf 
INSIGHTS INTO REGIONAL DEVELOPMENT

ISSN 2669-0195 (online) http://jssidoi.org/jesi/

2020 Volume 2 Number 1 (March)

http://doi.org/10.9770/IRD.2020.2.1(7)

\section{Aknowledgements}

This research was partly supported by Entrepreneurship and Sustainability Center, Lithuania

T. MAHARAJA, Dr. is a Faculty of Management at TIPS School of Management, Coimbatore, India. He is an innovative curriculum designer and an active and indigenous reseacher. He is currently writing research papers to enroll with and seek research grants from European Research Council in economic sustainability. Research interests: entrepreneurship and regional development; corporate innovation, global business innovation and future of small industries; business, economic and social sustainability.

ORCID ID: orcid.org/ 0000-0002-0866-4034

Register for an ORCID ID:

https://orcid.org/register

Copyright (C) 2020 by author(s) and VsI Entrepreneurship and Sustainability Center

This work is licensed under the Creative Commons Attribution International License (CC BY).

http://creativecommons.org/licenses/by/4.0/

c) (i) Open Access 